\title{
The inheritance of calyx morph variants in Primula vulgaris (Huds.)
}

\author{
M. A. Webster and \\ C. J. Grant
}

Department of Botany, University of Bristol, BS8 $1 \mathrm{UG}$, U.K.

Both "Hose-in-hose" and "Jack-in-the-Green" morphs of Primula vulgaris are controlled by unlinked alleles dominant to wild-type. In hose-in-hose the sepals are converted to a second whorl of petals; in jack-in-the-green they extend upwards as long sheathing leaves which persist as photosynthetic organs during and after capsule development. Breeding experiments indicate tight linkage between hose-in-hose and the $S$ s heteromorphy supergene, while jack-in-thegreen is inherited independently. Both morphs may vary in expression depending on the season and on the background genotype. Hybrids between the two have an intermediate phenotype with a petaloid calyx tipped with leafy lobes.

\section{INTRODUCTION}

Morphological variants of Primula species have been grown as horticultural specimens at least since Tudor times (Gerard, 1597; Parkinson, 1629). Few now survive outside specialist collections. In the "Hose-in-Hose" morph a switch occurs early in floral initiation which converts the normal calyx to a second corolla, such that one flower appears to grow out of another. Conversely in "Jack-in-theGreen" a later developmental reversion occurs so that the terminal lobes of the already developed calyx continue to grow as leaf-like appendages, extend to form a foliaceous ruff surrounding the corolla, and continue to photosynthesise, during and after capsule maturation. In natural situations selection against the hose-in-hose morph with its unprotected seed capsules might be expected. Observations during the experiments showed predation of capsules by slugs and premature dehiscence during hot weather. Conversely, the extra photosynthetic protective ruff of jack-in-the-green could be positively selected under some conditions.

Although there have been many previous studies of the Primula breeding system (e.g., Darwin, 1877; Mather and De Winton, 1941; Dowrick, 1956; Bodmer, 1958; Crosby, 1959; Richards, 1986) we are not aware of any previous studies of the genetics of these calyx morph variants or of their relationships to the $S s$ heteromorphy supergene.
Preliminary observations indicated that the hose-in-hose and jack-in-the-green plants used were dominant heterozygotes for the calyx mutations and that linkage exists between hose-in-hose and the $S s$ supergene. Controlled breeding of both morphs was undertaken, therefore, to determine their modes of inheritance, their relationships with the $S s$ supergene and their possible relationships and interactions with each other.

\section{MATERIALS AND METHODS}

\section{Sources of plants}

Wild type pin and thrum plants were taken from a hedge in Winford, Avon (ST 541648). Thrum hose-in-hose plants were grown from seed obtained from a single outcrossed plant bought from the late M. Mottram, North Molton, Devon in 1985. Pin and thrum jack-in-the-green plants were derived from a thrum garden hedge plant collected from Killay, Swansea (SS 600926) in 1980 and subsequently interbred with Winford wildtype plants. One pin (recombinant) hose-in-hose was raised in Winford in 1988.

\section{Crosses}

Six types of experimental cross were carried out:

(1) reciprocal cross of pin and thrum jack-in-thegreen $\times$ pin and thrum wild-type; 
(2) reciprocal cross of pin and thrum jack-in-thegreen $\times$ jack-in-the-green;

(3) wild-type pin $\times$ hose-in-hose thrum;

(4) the illegitimate self hose-in-hose thrum $\times$ hose-in-hose thrum;

(5) reciprocal cross of pin and thrum hose-inhose $\times$ hose-in-hose; and

(6) the reciprocal cross hose-in-hose thrum $x$ jack-in-the-green pin.

In all tables $H h: h h$ designates hose-in-hose heterozygous to wild-type recessive; $J j: j j$ designates jack-in-the-green heterozygous to wild-type recessive and $S s: s s$ is the Primula thrum to pin heteromorphy supergene.

\section{Pollination, harvesting and seed storage}

To prevent accidental self-fertilization all flowers to be cross-pollinated were emasculated by removal of the corolla and attached anthers. After hand pollination flowers were isolated in muslin bags. For self-pollination whole plants were enclosed in muslin bags and the surrounding soil was dusted regularly with B.H.C. insecticide. As capsules ripened, seeds were collected and stored in air-tight containers at $\sim 5^{\circ} \mathrm{C}$.

\section{Progeny testing}

Seeds harvested during Spring and Summer 1987 were sown on Levington seed compost in September 1987. As seedlings developed they were pricked out into pots and grown on in the greenhouse. Phenotypes were classified as plants came into flower during 1988 and 1989.

\section{RESULTS}

\section{Jack-in-the-Green and wild type}

When jack-in-the-green individuals are crossed with wild-type the progeny shows the $1 J S: 1 J_{S}: 1 j S: 1 j s$ phenotype ratio expected from a double heterozygote of unlinked gene loci crossed with the double recessive (table 1(a)). When they are crossed with each other, the progeny give a better fit with a $2: 1$ ratio than with a $3: 1$ ratio (table $1(\mathrm{~b})$ ). This indicates that homozygous $J J$ may be lethal. In the many preliminary crosses carried out but not reported here, it was never necessary to postulate a $J J$ parent to explain the progeny, and we are not aware of any horticultural true-breeding strains of jack-in-the-green.
Table 1(a) Jack-in-the-green $\times$ wild-type

\begin{tabular}{|c|c|c|c|c|}
\hline \multirow[b]{2}{*}{$\begin{array}{l}\text { Progeny phenotype } \\
\text { (Genotype) }\end{array}$} & & \multicolumn{2}{|c|}{ Reciprocal crosses } & \multirow[b]{2}{*}{ Total } \\
\hline & & $\begin{array}{l}j j s s \times \\
J j S s\end{array}$ & $\begin{array}{l}\text { JjSs } \times \\
\text { jjss }\end{array}$ & \\
\hline Jack-in-the-green (Jjss) & pin & 6 & 4 & 10 \\
\hline Jack-in-the-green (JjSs) & thrum & 5 & 3 & 8 \\
\hline Wild-type (jjss) & pin & 5 & 5 & 10 \\
\hline Wild-type $(j j S s)$ & thrum & 5 & 4 & 9 \\
\hline
\end{tabular}

18 jack-in-the-green: 19 wild-type. $\chi^{2}$ for $1: 1=0 \cdot 02.0 \cdot 8<P<$ 0.9 . jack-in-the-green

\begin{tabular}{lllll}
\hline & & \multicolumn{2}{l}{ Reciprocal crosses } \\
\cline { 2 - 4 } $\begin{array}{l}\text { Progeny phenotype } \\
\text { (Genotype) }\end{array}$ & & $\begin{array}{l}\text { Jjss } \times \\
\text { JjSs }\end{array}$ & $\begin{array}{l}\text { JjSs } \times \\
\text { Jjss }\end{array}$ & Total \\
\hline Jack-in-the-green $J j s s)$ & pin & 8 & 3 & 11 \\
Jack-in-the-green $(J j S s)$ & thrum & 10 & 4 & 14 \\
Wild-type $(j j s s)$ & pin & 7 & 2 & 9 \\
Wild-type $(j j S s)$ & thrum & 4 & 5 & 9 \\
\hline
\end{tabular}

31 jack-in-the-green: 18 wild-type (6 additional plants were $J j$--. Classified by persistent calyx, after capsules were too fully developed for recognition of $S s$ or $s s) \cdot \chi^{2}$ for $3: 1=3 \cdot 59$. P just $>0.05 . \chi^{2}$ for $2: 1=0.27 \cdot 0 \cdot 5<P<0.7$.

\section{Hose-in-Hose and wild-type}

In contrast with jack-in-the-green, where both pin and thrum plants could be crossed, when this study was initiated only thrum hose-in-hose plants were available, thus necessitating the illegitimate thrum $\times$ thrum self. The data indicate very tight linkage between the $H h$ locus and the $S s$ locus. The missing classes in tables 2(a) and 2(b) could only have been produced by crossover gametes. Although a large number of illegitimate self progeny were raised in the hope of finding the rare crossover product $H s$, none were found and the progeny (table $2(b)$ ) indicate a reasonable fit with the $2: 1$ ratio expected on the assumption that the $S S$ genotype is inviable (Richards, 1986). This would eliminate all $H H$ plants unless crossover between $H S$ and $h s$ produces an $H s$ gamete and an $H s / H s$ zygote. A proportion of the $H S$ progeny showed incomplete penetrance of the dominant gene $H$, having calyces with a mixture of petaloid and normal sepal material. Some showed developmental plasticity in the way $H$ was expressed.

Outside the controlled crosses one pin hose-inhose plant (jjHhss) was raised from naturally set seed collected from a pin jack-in-the-green (Jjhhss). The latter was growing near to the original 
Table 2(a) Pin wild-type $\times$ thrum hose-in-hose

\begin{tabular}{lll}
\hline $\begin{array}{l}\text { Progeny phenotype } \\
\text { (Genotype) }\end{array}$ & HhSs $\times h h s s$ \\
\hline $\begin{array}{ll}\text { Hose-in-hose }(H h s s) \\
\text { Hose-in-hose }(H h S s)\end{array}$ & pin & - \\
Wild-type $(h h S s)$ & thrum & 8 \\
Wild-type $(h h S s)$ & thrum & - \\
\hline
\end{tabular}

$\chi^{2}$ for $1: 1=0.06 .0 .8<P<0.9$.

Table 2(b) Hose-in-hose thrum $\times$ self illegitimate cross

\begin{tabular}{lll}
\hline $\begin{array}{l}\text { Progeny phenotype } \\
\text { (Genotype) }\end{array}$ & \\
\hline Hose-in-hose $(H-s s)$ & pin & - \\
Hose-in-hose $(H-S s)$ & thrum & 94 \\
Wild-type $(h h s s)$ & pin & 60 \\
Wild-type $(h h S s)$ & thrum & - \\
\hline
\end{tabular}

$\chi^{2}$ for $3: 1=16 \cdot 01 . P<0 \cdot 01$.

$\chi^{2}$ for $2: 1=2 \cdot 36.0 \cdot 1<P<0 \cdot 2$.

Table 2(c) Hose-in-hose thrum $\times$ hose in hose pin

\begin{tabular}{lllll}
\hline & \multicolumn{3}{l}{ Reciprocal crosses } \\
\cline { 2 - 4 } Progeny phenotype & & $\begin{array}{l}\text { HhSs } \times \\
\text { (Genotype) }\end{array}$ & Hhss $\times$ & \\
& & $H h s s$ & $H h S s$ & Total \\
\hline Hose-in-hose $(H-s s)$ & pin & 4 & 7 & 11 \\
Hose-in-hose $(H-S s)$ & thrum & 14 & 15 & 29 \\
Wild-type $(h h s s)$ & pin & 6 & 6 & 12 \\
Wild-type $(h h S s)$ & thrum & 0 & 0 & 0 \\
\hline
\end{tabular}

40 hose-in-hose: 12 wild type.

$\chi^{2}$ for $3: 1=0 \cdot 107.0 \cdot 7<P<0.8$.

29 thrum hose-in-hose: 11 pin hose-in-hose.

$\chi^{2}$ for $2: 1=0.596 .0 \cdot 3<P<0.5$.

thrum hose-in-hose and its progeny included other phenotypes consistent with a Jjhhss $\times$ jjHhss origin.

When this pin hose-in-hose $(H s / h s)$ was crossed with the thrum $(H S / h s)$, there was a $3: 1$ ratio of hose-in-hose to wild-type among the progeny which included a $2: 1$ ratio of thrum to pin in hose-in-hose plants (table 2(c)).

\section{Jack-in-the-Green and Hose-in-Hose}

When the two different calyx morphs are crossed, in 25 per cent of the progeny (table 3 ) $H$ and $J$ occur together giving an intermediate calyx morph, usually with leafy tips to the lobes of a petaloid calyx, or occasionally with petaloid insertions at the bases of some of the leafy calyx lobes. Only four phenotypes were found, occurring in the $1: 1: 1: 1$ ratio expected if almost total linkage exists between the $H h$ and $S s$ loci.

\section{DISCUSSION}

The progenies of crosses 3 and 4 (tables 2(a), 2(b)) indicate almost total linkage between the $H h$ and $S$ s loci. The lack of thrum wild-type in the cross 5 progenies (table 2(c)) supports this view, although the fortuitous occurrence of the hose-inhose pin used to make this cross shows that $H-S$ linkage is not absolute. It follows that the pin hose-in-hose progeny from cross 5 are almost certainly all $H s / h s$ while the thrums are probably a 1:1 ratio of $H s / h s$ to $H S / H s$. Identification of the latter should permit eventual production of a purebreeding hose-in-hose strain which could be of horticultural interest. The close linkage between $H$ and $S$ has potential for further genetic investigation of the $S s$ supergene.

Jack-in-the-green, in contrast to hose-in-hose, shows no linkage with $S$ and therefore none with $H$ (table 1(b)). It may be inviable as the $J J$ homozygote, as is SS (Richards, 1986) or as is "yellow mouse" (Eaton and Green, 1962) in the analogous mammalian situation. Progeny testing will determine whether or not this is so.

In some plants the calyx variants are more or less constant throughout the flowering season. In

Table 3 Hose-in-hose thrum $\times$ jack-in-the-green pin

\begin{tabular}{|c|c|c|c|c|}
\hline \multirow[b]{2}{*}{$\begin{array}{l}\text { Progeny phenotypes } \\
\text { (Genotype) }\end{array}$} & & \multicolumn{2}{|c|}{ Reciprocal crosses } & \multirow[b]{2}{*}{ Total } \\
\hline & & $j j H h S s \times J j h h s s$ & $J j h h s s \times j J H h S s$ & \\
\hline Jack-in-the-green (Jjhhss) & pin & 13 & 3 & 16 \\
\hline Hose-in-hose $(\mathrm{jjHhSs})$ & thrum & 6 & 2 & 8 \\
\hline Wild-type (jjhhss) & pin & 8 & 5 & 13 \\
\hline $\begin{array}{l}\text { Intermediate } \\
(\mathrm{JjHhSs})\end{array}$ & thrum & 9 & 4 & 13 \\
\hline
\end{tabular}

$\chi^{2}$ for $1: 1: 1: 1=2 \cdot 64.0 \cdot 3<P<0 \cdot 5$. 
others, presumably with different background genotypes, the expression of the morphs changes considerably as flowering proceeds. In these cases jack-in-the-green tends to be more fully expressed early in the flowering cycle with the calyx becoming almost wild-type later. In contrast hose-in-hose may start flowering with the petaloid calyx having a green midrib which, in buds developing later, is replaced by a completely petaloid outer "corolla". Some hose-in-hose plants with incomplete expression of the $H$ gene may initially appear wild-type, but later in the flowering cycle produce calyces streaked with petaloid material and/or have petaloid extensions to some of the calyx lobe margins. Use of the "fixed" expression plants may allow further genetic analysis of flower initiation.

The tight linkage of the $H$ and $S$ loci raises questions about the origins of the $H$ and $J$ mutations. The pin to thrum switch operates early in floral initiation to reverse stigma and anther length relationships and to alter the other coordinated anatomical and physiological characters coded by the $S s$ supergene. This may be due to a common trans-acting factor that activates a whole suite of tightly linked genes, which have the same activating sequence, within the heteromorphy supergene. $H$ may therefore have arisen as a tandem duplication of this activating sequence which now also coordinates a calyx to corolla change just a few cell divisions later in floral morphogenesis. Incomplete expression of $H$ may be a result of variable affinity of the trans-acting factor for the activating sequence. Perhaps this is analogous to the homoeotic mutations found in Drosophila and represents duplication of some sort of transcriptional activator or binding site similar to those found elsewhere in the animal kingdom (Robertson, 1988 ) or being searched for in the plant kingdom (e.g., Deikman and Fischer, 1988).

Although some controls of floral morphugenesis are linked within the heteromorphy supergene, it is clear that others are not, since $J$ is at least 50 centimorgans away and may not even be on the same chromosome as $H$ and $S$. Hence if $H$ and $J$ are due to insertion, deletion or mutation of a calyx activating sequence then in the case of $J$ this must have occurred at, or have been translocated to, a chromosome region unlinked with the heteromorphy supergene. If this is so, the apparent inviability of $J J$ would support the argument that it is eliminated like $S S$ by a similar process dependent on the same duplicated sequence. Only molecular studies will finally elucidate these problems.

Acknowledgements The authors would like to thank M. Ames for technical assistance and for expert horticultural advice. They are also grateful to Q. O. N. Kay, C. M. Lazarus, A. J. Richards, P. J. Rushton and S. R. J. Woodell for helpful comments on this paper.

\section{REFERENCES}

BODMER, W. F. 1959. Natural crossing between homostyle plants of Primula vulgaris. Heredity, 12, 363-370.

CROSBY, J. 1959. Outcrossing on homostyle primroses. Heredity, $13,127-131$.

DARWIN, C. 1877. The Different Forms of Flowers on Plants of the Same Species. John Murray, London.

DEIKMAN, J. AND FISCHER, R. L. 1988. Interaction of a DNA binding factor with the 5 -flanking region of an ethyleneresponsive gene from tomato. EMBO J. 7, 3315-3320.

Dowrick, V. P. J. 1956. Heterostyly and homostyly in Primula obconica. Heredity, 10, 219-236.

EATON, G. J. AND GREEN, M. M. 1962. Implantation and lethality of the yellow mouse. Genetics, 33, 106-112.

GERARD, G. 1597. The Herball or General Historie of Plants. John Norton, London.

MATHER, K. AND DE WINTON, D. 1941. Adaptation and counteradaption of the breeding system in Primula. Ann. Bot., N.S., 5, 297-311.

PARKINSON, J. 1629. Paradisi in Sole. Paradisus Terrestris. Reprinted 1904. Methuen and Co., London.

RICHARDS, A. J. 1986. Plant Breeding Systems. Allen and Unwin Ltd., London.

ROBERTSON, M. 1988. Homoeo boxes, POU proteins and the limits to promiscuity. Nature, 336, 522-524. 